\title{
The Effect of a Communication and Conflict Resolution Skill Training Program on the Social Skill Levels of University Students
}

\author{
T. Fikret KARAHAN*
}

\begin{abstract}
In this resaarch, the effect of communication and conflict resolution skill training program with 10 sessions which was developed by researcher on the social skill levels of university students are examined. The study was carried out on the 28 students, 14 participants in the control group, 14 participants in the experimental group who are students Ondokuz Mayıs University. The desing of the research was based on an experimental pre-test and posttest model. Students' social skill levels was measured by means of Social Skill Inventory which was adopted to Turkish by Yüksel (2000). Data analysis was applied Independent Samples t-test, Paired Samples t-test and One-Way ANOVA for Repeated Measures techniques were applied for statistical analysis. The research pointed out that social skill levels of students who attended communication and conflict resolution skill training program were higher than those of others $(\mathrm{p}<.001)$. In general, results have showed that Communication and Conflict Resolution Skill Training Program may effect university students social skill levels positively. After the posttest application with three months and six months follow after studies it was found that there was no significant difference between Social Skill Inventory test scores of post-test, first following study, and second following study.
\end{abstract}

Key Words: Communication and Conflict Resolution Skill Training Program, Social Skill, University Student.

\footnotetext{
Asist.Prof.Dr. T.Fikret Karahan, Ondokuz Mayıs University Faculty of Education Department of Educational Sciences, tfikretkarahan@hotmail.com
} 


\section{SUMMARY}

In this study, it was stated that university students with low levels of social skills levels have gained some social skills with communication and conflict resolution skill training program and their social skill levels have increasing. According to this statement and explanations in this study, within the literature and to the universirty students efficiency of the "Communication and Conflict Resolution Skill Training Program" was investigated. In this study; it was stated that students who have attended to the Ondokuz Mayıs University can be apply to the "Communication and Conflict Resolution Skill Training Program" with group life and 10 sessions. 163 voluntary students were taken the Social Skill Inventory pre-test application. At the end of the application 28 students whose SSI total scores low than other students constitude the working group of the sample. In this study, control group pre-test post-test model were used. Before the communication and conflict resolution skill training program, experimental and control group were taken SSI pre-test applications. Experimental group were taken 10 sessions and 90 minutes peer week communication and conflict resolution skill training program, control group were not taken any application. At the end of these sessions, efficiency of the program were measured with posttest scores of experimental and control groups. High social skill levels of the students in the experimental group will examined as permanently scores with after three and six months after the post-tes scores.

Social Skill Inventory: Students' social skill levels was measured by means of Social Skill Inventory which was adopted to Turkish by Yüksel (2000). Adaptation of the Social Skill Inventory which was developed by Riggio (1989) was made by Yüksel (2000). Each subscale contains 15 items, and six subscale contains 90 items and there were 32 items. Likert type with 5 items scale were used in Social Skill Inventory. High score from the scale indicate high social skill level, low score indicate low social skill level.

The Communication and Conflict Resolution Skill Training Program:

Program was developed within eclectic approach with many references from literature. Program was developed according to the instructive, living, structural and time limited factors. Communication and Conflict Resolution Skill Training Program was applicated to the experimental group with group life with ten sessions at the weekend within 90 minutes. In the sessions there were skill according to the structured information, rol-playing with group life and scenario and skill with homework activities. After each session evaluation was made with test subjects and skills which are learned from the program applied to the daily life with some homeworks. Sessions were summarized as follows:

1. Session: In the first session group members were meet and information were given about the 10 sessions skill program, group procedure, and attendence to the group sessions.

2. Session: Greating each other, meeting, acceptance in communication and skill of tarnsmiting respect. 
3. Session: To see the negative effects of the ego shamefull language and skill of using developing ego language.

4. Session: To see the negative effects of the insufficient listening styles and the skill of using efficiency listening skill.

5. Session: To see the negative effects of the "you" languge in communication and the skill of using "I" language in expression of positive and negative feelings.

6. Session: To establish empatic relationships with others and react right empatic behavior skills.

7. Session: Control of anger and to state with "I" langauage, using humor and relaxation techniques in control of anger.

8. and 9. Session: To share conflicts in their earlier life, to display emotions and behaviors in conflict situtations with role playing, to become consider communication difficulties in conflict situations, in conflict situations instead of aggresiveness behaviors positive and cooperative behaviors with role playing and discussing, in conflict situations focus on the others' body language and the skill of become aware of basic emotions.

10. Session: In the last session group life and emotions were shared, program was evaluated with group members and program was finished with Love Bomb.

Result: The findings of the study indicated that Communication and Conflict Resolution Skill Training Program has positive effects on the university students in experimental groups in terms of the increasing in social skill levels $(p<.001)$. It was think about that first and second follow up tests results can be determined the long terms or short terms effects of the program with group life in the experimental group.

Discussion: With the program group members were given some basic applications these are; meeting and gereeting in communication, transmit acceptance and respect, using ego developing language, using of efficient listening skill, to state positive and negative feelings with "I" language, giving empatic react with high level, controling of anger and expressing with "I" language, in conflict situations instead of aggressiveness behaviors positive and manding hehaviors. understanding others' hodv language. These annlications 


\title{
Bir İletişim ve Çatışma Çözme Beceri Eğitimi Programı'nın Üniversite Öğrencilerinin Sosyal Beceri Düzeylerine Etkisi
}

\author{
T. Fikret KARAHAN*
}

Öz. $\mathrm{Bu}$ araştırmada, araştırmacı tarafından geliştirilen 10 oturumluk İletişim ve Çatışma Çözme Beceri Eğitimi Programı'nın üniversite öğrencilerinin sosyal beceri düzeyleri üzerindeki etkisi incelenmiştir. Çalışma grubu Ondokuz Mayıs Üniversitesi'nde öğrenim gören 28 öğrenciden oluşturulmuştur. Araştırma deseni olarak kontrol gruplu ön-test son-test model kullanılmış ve 14 öğrenci deney, 14 öğrenci kontrol grubuna alınmıştır. Öğrencilerin sosyal beceri düzeyleri Riggio (1989) tarafindan geliştirilen ve Türkiye uyarlaması Yüksel (2000) tarafindan yapılan "Sosyal Beceri Envanteri" ile ölçülmüştür. Verilerin analizinde Bağımsız Örneklemler İçin t-testi, İlişkili Örneklemler İçin t-testi ve İlişkili Örneklemler İçin Tek Yönlü ANOVA Testi teknikleri kullanılmıştır. Araştırma bulguları; İletişim ve Çatışma Çözme Beceri Eğitimi Programı'na katılan öğrencilerin sosyal beceri düzeylerinin, bu programa katılmayan öğrencilerin sosyal beceri düzeylerinden yüksek olduğunu ortaya koymuştur $(\mathrm{p}<.001)$. Son-test ölçümünden üç ve altı ay sonra yapılan iki ayrı izleme çalışmasında ise deney grubunda programın olumlu etkisinin devam ettiği gözlenmektedir. Elde edilen bu sonuç doğrultusunda, İletişim ve Çatışma Çözme Beceri Eğitimi Programı'nın, öğrencilerin sosyal beceri düzeylerini olumlu ve kalıcı yönde etkilediği ileri sürülebilir.

Anahtar Sözcükler: İletişim ve Çatışma Çözme Beceri Eğitimi Programı, Sosyal Beceri, Üniversite Öğrencisi.

\section{GİRIŞ̧}

İnsan, bir makine ya da bilgisayar ile değil de başka insanlarla etkileşime girmeye başladığında sosyal beceriler gündeme gelmekte (Abbott \& Lewry, 1991) ve toplumsal yaşamda başka insanlarla olumlu ilişkiler

\footnotetext{
* Yrd.Doç.Dr., Ondokuz Mayıs Üniversitesi Eğitim Fakültesi, Eğitim Bilimleri Bölümü Psikolojik Danışma ve Rehberlik Anabilim Dalı, <tfikretkarahan@hotmail.com>
} 
kurabilmek ve sürdürebilmek için organize olmuş bir dizi davranışsal beceriye ihtiyaç duymaktadır (Kelly, 1982). Sosyal beceri olarak nitelenen bu beceriler kişilerarası ilişkilerde başarılı olabilmek için ön-koşul niteliğinde olup, çocukluk döneminden itibaren öğrenme yoluyla kazanılmaya başlanmakta ve yaşam boyu kullanılmaktadır. Sosyal beceriler bireyin diğer bireylerle olumlu ilişkiler kurmasını sağlamakla birlikte, ihtiyaçlarını karşılamasına ve amaçlarına ulaşmasına da yardımcı olmaktadır (Cartledge \& Milburn, 1992). Böylece toplumsal uyumun başarılı bir biçimde sürebilmesi için bireyin kendisinden farklı olan insanlara saygı gösterme, insanların kendisine benzemesini beklememe, duygu ve düşüncelerini insanlarla paylaşma, insanlara karşı kabul ve onay tepkileri verme gibi olumlu ve işlevsel becerileri günlük yaşamda zincirleme bir şekilde sergilemesi gerekmektedir (Fontana, 1992).

Sosyal beceri; sözel ve sözel olmayan davranışlarla kişilerarası ilişkilerde kendini ifade edebilme (Ogilvy, 1994), karş11ıklı güven içinde iletişim kurma, iletişimi sürdürme, gerekli durumlarda liderlik yapabilme ve çatışmaları çözebilme becerisi (Elliott \& Gresham, 1987; Goodwin, 1999), uygun biçimde duygu ve düşüncelerini paylaşma ve başka bireylerin de duygu ve düşüncelerini paylaşmalarına yardımcı olma, verilen görevleri başarabilme (Becker, Heimberg \& Bellack, 1987; Gresham, 1986) ve toplumsal yaşamda başarılı olabilmek için gerekli olan davranışları sergileme becerisi olarak tanımlanmaktadır (Spence, 2003). Burada verilen tanımlarla ilişkili olarak birçok araştırmacı sosyal yeterlilik ve sosyal uyum için sosyal becerileri ön-koşul olarak görmektedir (Cavell, 1990; Gresham, 1986). Begun (1996), kişilerarası iletişimde en önemli sosyal beceri olarak dinleme becerisinin kullanıldığını belirtmektedir. Benzer biçimde Hargie, Sounders \& Dickson da (1994) temel sosyal becerileri sözel olan ve sözel olmayan iletişim becerileri olarak gruplandırmaktadır. Bunlardan; baş sallama, mimikler, beden duruşu, ses tonu ve göz teması gibi tepkileri sözel olmayan beceriler olarak gruplandırmaktadır. Sözel olan becerileri ise soru sorma, geri-bildirim verme, duygu ve düşüncelerini açık olarak ifade etme, dinleme ve güvengenlik olarak siralamaktadır. Riggio (1986) ise temel sosyal becerileri anlatımcılık ve duyarlık olarak iki gruba ayırmakta ve bu iki temel sosyal beceriyi de; duyuşsal anlatımcılık, duyuşsal duyarlık, sosyal anlatımcilık, sosyal duyarlık, duyuşsal kontrol ve sosyal kontrol olarak alt gruplara ayırmaktadır. Bunları kısaca özetlemek gerekirse duyuşsal anlatımcılık diğer bireyleri etkilemeye yönelik becerileri; duyuşsal duyarlık karşıdaki bireylerin duygu ve düşüncelerinin farkında olma becerilerini; sosyal anlatımcılık sözel ifade, sözel akıc1lık, karşılıklı konuşabilme ve görüş alış-verişinde bulunabilme becerilerini ifade etmektedir. Sosyal 
duyarlık ise başkalarından gönderilen sözel mesajları alma, anlama, toplumsal kuralları öğrenme ve buna göre davranma becerilerini ifade etmektedir. Diğer bir sosyal beceri alanı olan duyuşsal kontrol, duyuşsal iletişimi ve sözel olmayan ifadeleri düzenleme becerisini ifade etmekte; sosyal kontrol ise insanlara karşı sergilenen sözel mesajların ve davranışların düzenlenmesi ve kendini ifade becerileri olarak açıklanmaktadır.

Yapılan birçok araştırmada sosyal becerilerde gözlenen yetersizliğin olumsuz sonuçları üzerinde durulmaktadır. Bunları kısaca özetlemek gerekirse; sosyal beceri düzeyi düşük olan bireylerin saldırganlık, suç işleme, duygusal sorunlar, madde kullanma, yalnızlık, yüksek düzeyde risk içeren cinsel davranışlar, düşük akademik başarı, okuldan atılma, depresyon ve yüksek kayg1 (Elliott \& Gresham, 1987; Fox \& Boulton, 2003; Hamarta, 2000; Hansen, Nangle \& Meyer, 1998; Harman, Hansen, Cochran, \& Lindsey, 2005; Huprich, Clancy, Bornstein, \& Nelson-Gray, 2004; Matson, Smiroldo \& Bamburg, 1998; Nangle \& Hansen, 1998; Riggio, Tucker \& Coffaro, 1989; Spence, 2003; Segrin, 2001) gibi sorunları diğer bireylere göre daha çok yaşadıkları rapor edilmektedir. Spirito ve Hartford da (1990) sosyal beceri düzeyi düşük olan bireylerin, günlük sorunlarla başaçıkmada ve kişilerarası ilişkileri sürdürmede yaşadıkları yetersizlik nedeniyle daha mutsuz olduklarını belirtmektedir. Yukarıda yapılan açıklamalarda sosyal becerilerin doğum sonrasında öğrenme yoluyla kazanıldığı vurgulanmıştı. Bununla ilişkili olarak yapılan araştırmalarda; günlük yaşamdaki sorunlarla ve değişimlerle başaçıkabilmelerine yardımcı olabilme amacıyla sosyal becerileri zayıf olan çocuklara, ergenlere ve yetişkinlere yönelik soysal beceri eğitimine ağırlık verilmesi gerektiği rapor edilmektedir (Elksnin \& Elksnin, 1998; Ogilvy, 1994). Albee de (1999) psiko-sosyal sorunlar sosyal becerilerin zayıf olması nedeniyle ortaya çıktığı için bu tip becerilerin öğretilebileceğini ve psiko-sosyal sorunların önlenebileceğini belirtmektedir (Akt: Korkut, 2004).

Son yıllarda sosyal beceri konusunda yapılan araştırmalar, farklı gelişim dönemlerindeki bireylerin sosyal becerilerini geliştirmeye dönük programlar üzerinde yoğunlaşmaktadır (Anderson-Butcher, Newsome \& Nay, 2003; Antshel \& Remer, 2003; Bullis, Walker \& Sprague, 2001; Elksnin \& Elksnin, 1998; Elliott, Pring \& Bunning, 2002; Fox \& Boulton, 2003; Goodwin, 1999; Leukefeld, Godlaski, Clark, Brown \& Hays, 2002; Ogilvy, 1994; Spence, 2003; Takahashi \& Kosaka, 2003; Thompson \& Bundy, 1996; Wise \& Bundy, 1991; Yüksel, 1999). Bu programlar incelendiğinde çoğunluğunun ilköğretim ve ortaöğretim öğrencilerini hedeflediği görülmektedir. Bu açıdan ele alındığında temel sosyal becerilerin üniversite düzeyinde değil de zaman kaybetmeden ilköğretim ya da en geç ortaöğretim 
düzeyinde kazandırılması zorunluluğu ön plana çıkmaktadır. Türkiye koşullarında değerlendirildiğinde ise iletişim ve çatışma çözme becerilerini geliştirmeye dönük programların geç sayılsa bile henüz üniversite düzeyinde dahi yaygınlaşamadığı görülmektedir.

\section{Problem}

Yukarıda yapılan açıklamalara dayalı olarak bu araştırmada; sosyal beceri düzeyi düşük olan üniversite öğrencilerine iletişim ve çatışma çözme beceri eğitimi verilerek, onların sosyal beceri düzeylerinin yükseltilebileceği düşüncesinden hareket edilmiştir. Çünkü yukarıda da açıklandığı gibi temel iletişim ve çatışma çözme becerileri öğrenme yoluyla kazanılabilmektedir. Ayrıca sosyal becerilerin hem alt yapısını hem de içeriğini oluşturmaktadır. $\mathrm{Bu}$ düşünceye ve yukarıda yapılan kuramsal açıklama ve ampirik araştırmalara bağlı olarak bu araştırmada; üniversite öğrencilerine dönük olarak literatür 1şığında geliştirilen İletişim ve Çatışma Çözme Beceri Eğitimi Programı'nın, üniversite öğrencilerinin sosyal beceri düzeyleri üzerindeki etkililiğinin incelenmesi amaçlanmıştır. Burada açıklanan amaca yönelik olarak araştırmada aşağıdaki denenceler test edilmiştir:

1. Deney grubunda yer alan öğrencilerin Sosyal Beceri Envanteri sontest toplam puanları, kontrol grubunda yer alan ögrencilerin son-test toplam puanlarına göre daha yüksektir.

2. Deney grubunda yer alan öğrencilerin Sosyal Beceri Envanteri sontest toplam puanları, ön-test toplam puanlarına göre daha yüksektir.

3. Deney grubunda yer alan öğrencilerin Sosyal Beceri Envanteri sontest toplam puanları ile üç ve altı ay sonra uygulanan izleme testi toplam puanları arasında anlamlı bir fark bulunmamaktadır.

\section{YÖNTEM}

Araştırma; İletişim ve Çatışma Çözme Beceri Eğitimi Programı'nın üniversite öğrencilerinin sosyal beceri düzeylerine etkisini incelemeye yönelik, kontrol gruplu ön-test son-test modelin kullanıldığı deneysel bir çalışmadır.

\section{Araştırmaya Katılan Bireyler}

Araştırmada; Ondokuz Mayıs Üniversitesi Eğitim Fakültesi'ne devam eden öğrencilere duyuru yapılarak, grup yaşantısına dayalı 10 oturumluk "İletişim ve Çatışma Çözme Beceri Eğitimi Programı" uygulanacağ 1 bildirilmiştir. Bu programa gönüllü olarak katılabileceklerini belirten 163 öğrenciye Sosyal Beceri Envanteri (SBE) ön-test uygulaması yapılmıştır. Bu uygulama sonucunda SBE toplam puanları, diğer öğrencilere göre en düşük 
olan (puanları $\min =202, \max =263$ arasında olan) öğrencilerden 28 kişilik bir grup araştırmanın çalışma grubunu oluşturmuştur. Araştırmanın gruplarını oluşturmak için seçkisiz örnekleme yöntemiyle 14 kişiden oluşan deney ve 14 kişiden oluşan kontrol grubu olmak üzere iki grup kurulmuştur. Deney grubundaki öğrencilerin 6'sı kız 8'i erkek olup yaşları 19-23 arasında değişmektedir. Kontrol grubu ise yaşları 19-24 arasında değişen 9'u erkek 5'i kız öğrenciden oluşmaktadır. Deney ve kontrol gruplarındaki öğrencilerin; daha önce herhangi bir psikiyatrik tanı almadıkları ve geçmiş yaşamlarını çoğunlukla küçük yerleşim birimlerinde geçirdikleri saptanmıştır. Öğrenim gördükleri bilim dalları açısından bakıldığında ise gruplardaki öğrencilerin; Yabancı Diller, Sınıf Öğretmenliği, Okulöncesi Eğitim, Sosyal Bilgiler ve Bilgisayar Teknolojileri Öğretmenliği bölümlerinde öğrenim gördükleri gözlenmektedir. Deney ve kontrol gruplarının SBE ön-test toplam puanları arasında anlamlı bir fark olup olmadığını test edebilme amaciyla, veriler üzerinde Bağımsız Örneklemler İçin t-testi tekniği uygulanmış ve elde edilen sonuç Tablo 1'de verilmiştir.

Tablo 1. Deney ve kontrol grubunda yer alan ögrencilerin SBE ön-test toplam puanlarına ilişkin t-testi sonuçları

\begin{tabular}{ccccccc}
\hline Gruplar & $\mathrm{n}$ & $\begin{array}{c}\text { Sosyal Beceri } \\
\text { Envanteri Puan } \\
\text { Ortalamaları } \\
\mathrm{X}\end{array}$ & Ss & Sd & $\mathrm{t}$ & $\mathrm{p}$ \\
\hline Deney & 14 & 228.85 & 14.31 & 26 & .026 & .979 \\
Kontrol & 14 & 228.71 & 14.40 & & & \\
\hline
\end{tabular}

Tablo 1'de yer alan istatistiksel veriler, deney ve kontrol gruplarında bulunan öğrencilerin, program uygulanmadan önce SBE ön-test toplam puanları arasında anlamlı bir farkın bulunmadığını göstermektedir. Elde edilen bu sonuca dayalı olarak, araştırmanın başında deney ve kontrol gruplarının sosyal beceri düzeyleri açısından istatistiksel olarak denk ya da benzer özelliklere sahip oldukları ileri sürülebilir.

\section{Araştırma Deseni}

$\mathrm{Bu}$ araştırmada, araştırma deseni olarak Kontrol Gruplu Ön-test Sontest Model kullanılmıştır. Araştırmanın bağımsız değişkeni olan iletişim ve çatışma çözme beceri eğitimi verilmeden önce, deney ve kontrol gruplarına SBE ön-test uygulaması yapılmıştır. Deney grubuna 10 oturumluk ve haftada bir buçuk saatlik oturumlar şeklinde iletişim ve çatışma çözme beceri eğitimi verilmiş, kontrol grubu ise beklemeye alınmıştır. Program sonunda, programın grup üyelerinin sosyal beceri düzeyleri üzerindeki etkililiğini saptama amacıyla deney ve kontrol gruplarına SBE son-test 
uygulaması yapılmıştır. Daha sonra çağrı yapılarak program kontrol grubuna da uygulanmıştır. Deney grubunda yer alan öğrencilerin sosyal beceri düzeylerini izleme amacıyla son-test uygulamasından üç ve altı ay sonra SBE tekrar uygulanmıştır. Kontrol grubunun ön-test ve son-test ölçümleri arasında anlamlı bir fark gözlenmediği için izleme çalışması yapılmamıştır.

\section{Veri Toplama Aracı}

Araştırmada problemin incelenebilmesi için gerekli olan veriler Sosyal Beceri Envanteri ile toplanmıştır. Ayrıca araştırmaya katılan bireylerin demografik özellikleri ile ilgili bilgiler ise Kişisel Bilgi Formu ile toplanmıştır. Kişisel Bilgi Formu'nda; daha önce psikiyatrik bir tanı alıp almadıkları, uzun süre yaşadıkları yerleşim birimi, yaş, bölüm ve cinsiyete yönelik sorulara yer verilmiştir.

\section{Sosyal Beceri Envanteri (SBE)}

Riggio (1989) tarafindan geliştirilen envanterin Türkiye uyarlaması Yüksel (2000) tarafından yapılmıştır. Test tekrar-test yöntemi ile hesaplanan toplam puana ilişkin güvenirlik katsayısı tüm ölçek için 0.92 olarak bulunmuştur. Alt ölçeklerden elde edilen güvenirlik katsayıları ise Duyuşsal Anlatımcılık için 0.81; Duyuşsal Duyarlık için 0.87; Duyuşsal Kontrol için 0.80; Sosyal Anlatımcılık için 0.89; Sosyal Duyarlık için 0.88 ve Sosyal Kontrol için 0.89 olarak hesaplanmıştır. Toplam puana ilişkin iç tutarlık (Cronbach Alpha) katsayısı ise 0.85 olarak bulunmuştur. Alt ölçeklere göre elde edilen iç tutarlık katsayıları ise Duyuşsal Anlatımcılık için 0.56; Duyuşsal Duyarlık için 0.80; Duyuşsal Kontrol için 0.75; Sosyal Anlatımcılık için 0.82; Sosyal Duyarlık için 0.72 ve Sosyal Kontrol için 0.81 olarak hesaplanmıştır. Geçerlik çalışmasında kapsam ve benzer ölçekler geçerliği olmak üzere iki yöntem kullanılmıştır. Kapsam geçerliği ile ilgili çalışmada (uzman kanısı), ölçeğin sosyal becerileri ölçebilecek nitelikte olduğu bildirilmiştir. Benzer ölçekler geçerliği için Kendini Ayarlama Ölçeği kullanılmış ve her iki ölçekten elde edilen puanlar arasında 0.63 $(n=37)$ korelasyon bulunmuştur. Envanterin alt ölçekleri ile Kendini Ayarlama Ölçeği puanları arasındaki korelasyon katsayıları ise -0.21 ile 0.57 arasında değişmektedir. Envanterin bütününe ilişkin benzer ölçekler geçerlik katsayısı 0.001 düzeyinde, alt ölçeklere ilişkin katsayıları ise 0.01 düzeyinde anlamlı bulunmuştur. Sosyal Beceri Envanteri'nin her bir alt ölçeğinde 15'er madde olmak üzere, altı alt ölçekte toplam 90 madde bulunmaktadır. Ölçekten alınabilecek puanlar 90 ile 450 arasında değişmekte olup, yüksek puan sosyal beceri düzeyinin yüksek olduğunu ifade etmektedir.

\section{İletişim ve Çatışma Çözme Beceri Eğitimi Programı}


Araştırmanın bağımsız değişkeni, ön-test ve son-test uygulamaları arasında gerçekleştirilen grup yaşantısına dayalı İletişim ve Çatışma Çözme Beceri Eğitimi Programı'dır. Program araştırmacı tarafından birçok kaynaktan yararlanılarak eklektik bir yaklaşımla geliştirilmiştir (Baltaş \& Baltaş, 1992; Breunlin, Bryant-Edwards \& Hetherington, 2002; Cüceloğlu, 1995; Çağdaş, 2002; Dökmen, 1995; Durant, Barkın \& Krowchuk, 2001; Dysinger, 1993; Egan, 1975; Gordon, 1998; Gordon \& Sands, 1998; Graves, Nordling, Roberts, \& Taylor, 1997; Hazaleus \& Deffenbacher, 1986; Inger, 1991; Lane-Garon, 2000; Pettit, 1995; Schroeder, Basken, Engstrom \& Heald, 2000; Selçuk \& Güner, 2000; Stevahn \& Johnson, 1997; Whirter \& Voltan-Acar, 1998; Voltan-Acar, 2002). Program davranış kazandırmaya yönelik, yaşantısal ve yapılandırılmış bir yapıya uygun biçimde geliştirilmiştir. Program her hafta sonu yaklaşık bir buçuk saatlik oturumlar şeklinde 10 oturumda gerçekleştirilmiştir. Oturumlarda beceri ile ilgili yapılandırılmış bilgi sunma, beceri ile ilgili yaşantıya ve senaryoya dayalı rol oynama ve beceri ile ilgili ödevlendirme gibi uygulamalara yer verilmiştir. Her oturumdan sonra ise programa katılan deneklerle birlikte değerlendirme yapılmış ve kazandıkları beceriyi günlük yaşantıya aktarmaları doğrultusunda ev ödevi verilmiştir. Oturumlarda kazandırılması hedeflenen beceriler aşağıda özetlenmiştir:

1. Oturum: İlk oturumda üyelerin tanışması sağlanmış ve 10 oturumluk beceri eğitimi programı, grubun işleyişi ve oturumlara devam konusunda bilgilendirme yapılmıştır.

2. Oturum: İletişimde tanışma, selamlaşma, kabul ve saygıyı iletebilme becerisi,

3. Oturum: Ego aşağılayıcı dil ile gönderilen mesajların olumsuz etkilerini görebilme ve iletişimde ego geliştirici dili kullanabilme becerisi,

4. Oturum: Sağlıksız dinleme türlerinin iletişim sürecindeki olumsuz etkilerini görebilme ve iletişimde etkin dinleme becerisini kullanabilme becerisi,

5. Oturum: Sen dili ile mesaj göndermenin iletişimde olumsuz etkilerini görebilme; olumlu ve olumsuz duyguları ben dili kullanarak ifade edebilme becerisi,

6. Oturum: Başkalarıla empati kurabilme ve ileri düzeyde doğru empatik tepki verebilme becerisi,

7. Oturum: Öfkeyi kontrol edebilme ve ben dili kullanarak ifade edebilme, öfke kontrolünde mizah ve gevşeme tekniklerini kullanabilme becerisi, 
8. ve 9. Oturum: Geçmişte yaşadığı çatışmaları grupla paylaşma, çatışma karşısında yaşadığı duyguları ve sergilediği davranışları rol oynama yoluyla grupta sergileme. Çatışma durumunda sergilenen iletişim engellerinin farkına varabilme, çatışma karşısında saldırgan ve zorba tepkiler sergileme yerine yapıcı ve işbirliğine dayalı tutum sergilemeye dönük rol oynama ve sonuçlarını tartışma, çatışma sürecinde başkalarının beden diline odaklanabilme ve temel duyguları fark edebilme becerisi,

10. Oturum: Son oturumda grup yaşantısı ile ilgili duygular paylaşılmış, üyelerle birlikte programın değerlendirmesi yapılmış ve Sevgi Bombardımanı Oyunu (Voltan-Acar, 2002) ile program sonlandırılmıştır.

\section{Verilerin Analizi}

Araştırmada verilerin normal dağılım gösterip göstermediğini saptama amacıyla Kolmogorov-Smirnov Testi, varyansların homojen olup olmadığını test etme amaciyla Levene Testi (Ural ve Kılıç, 2005) uygulanmıştır. Analizler sonucunda gruplara ait ölçümlerin normal dağılım sergilediği $(\mathrm{P}=0.625 ; \mathrm{p}>.05)$ ve varyansların homojen olduğu $(\mathrm{P}=1 ; \mathrm{p}>.05)$ saptanmıştır. $\mathrm{Bu}$ nedenle verilerin analizinde parametrik testlerden Bağımsız Örneklemler İçin t-testi, İlişkili Örneklemler İçin t-testi ve İlişkili Örneklemler İçin Tek Yönlü ANOVA Testi (Repeated Measures) teknikleri kullanılmış olup (Büyüköztürk, 2003), SPSS 11.5 paket programından yararlanılmıştır. Sonuçların yorumlanmasında 0.05 anlamlılık düzeyi üst değer olarak alınmıştır.

\section{BULGULAR}

Bu bölümde araştırmanın denencelerini test edebilmek amacıyla yapılan istatistiksel analizler sonucu elde edilen bulgulara ve ilgili tablolara yer verilmiştir.

Denence 1: "Deney grubunda yer alan öğrencilerin Sosyal Beceri Envanteri son-test toplam puanları, kontrol grubunda yer alan öğrencilerin son-test toplam puanlarına göre daha yüksektir".

$\mathrm{Bu}$ denenceyi test edebilme amaciyla deney ve kontrol grubunda yer alan öğrencilerin SBE son-test toplam puanları üzerinde Bağımsız Örneklemler İçin t-testi tekniği uygulanmış ve sonuç Tablo 2'de verilmiştir. Tablo 2'de yer alan istatistiksel veriler; deney ve kontrol grubunda yer alan öğrencilerin SBE son-test toplam puanları arasındaki farklılığın 0.001 düzeyinde, deney grubu lehine anlamlı olduğunu göstermektedir. Bu sonuç araştırmanın birinci denencesini doğrulamaktadır. 
Tablo 2 . Deney ve kontrol grubunda yer alan ögrencilerin SBE son-test toplam puanlarına ilişkin t- testi sonuçları

\begin{tabular}{lcccccc}
\hline Gruplar & $\mathrm{n}$ & $\begin{array}{c}\text { Sosyal Beceri } \\
\text { Envanteri Puan } \\
\text { Ortalamaları } \\
\text { X }\end{array}$ & Ss & Sd & $\mathrm{t}$ & $\mathrm{p}$ \\
\hline Deney & 14 & 331.42 & 35.14 & 26 & 10.39 & .000 \\
Kontrol & 14 & 227.21 & 13.06 & & & \\
\hline
\end{tabular}

Denence 2: "Deney grubunda yer alan öğrencilerin Sosyal Beceri Envanteri son-test toplam puanları, ön-test toplam puanlarına göre daha yüksektir".

$\mathrm{Bu}$ denenceyi test edebilme amaciyla deney grubunda yer alan öğrencilerin SBE ön-test ve son-test toplam puanları üzerinde İlişkili Örneklemler İçin t-testi tekniği uygulanmış ve sonuç Tablo 3'te verilmiştir. Tablo 3'te yer alan istatistiksel veriler, deney grubunda yer alan öğrencilerin SBE ön-test ve son-test toplam puanları arasındaki farklılığın, son-test uygulaması lehine 0.001 düzeyinde anlamlı olduğunu göstermektedir. $\mathrm{Bu}$ sonuç, araştırmanın ikinci denencesini doğrulamaktadır.

Tablo 3. Deney grubunda yer alan ögrencilerin SBE ön-test ve son-testtoplam puanlarına ilişkin t-testi sonuçları

\begin{tabular}{cccccccc}
\hline $\begin{array}{c}\text { Deney } \\
\text { Grubu } \\
\text { Ölçüm }\end{array}$ & $\mathrm{n}$ & $\begin{array}{c}\text { Sosyal Beceri } \\
\text { Envanteri Puan } \\
\text { Ortalamaları } \\
\text { X }\end{array}$ & Ss & Sd & t & & $\mathrm{p}$ \\
\hline Ön-test & 14 & 228.85 & 14.31 & 13 & 11.87 & .000 \\
Son-test & 14 & 331.42 & 35.14 & & & \\
\hline
\end{tabular}

Denence 3: "Deney grubunda yer alan öğrencilerin Sosyal Beceri Envanteri son-test toplam puanları ile üç ve altı ay sonra uygulanan izleme testi toplam puanları arasında anlamlı bir fark bulunmamaktadır".

$\mathrm{Bu}$ denenceyi test edebilme amaciyla deney grubundaki öğrencilerin SBE ön-test, son-test, I. izleme testi ve II. izleme testi toplam puanları üzerinde İlişkili Örneklemler İçin Tek Yönlü ANOVA Testi uygulanmış ve elde edilen sonuç Tablo 4'te verilmiştir. Tablo 4'te yer alan veriler; SBE ön-test, son-test ve I. izleme testi puanları arasında, son-test ve I. izleme testi lehine anlamlı bir farklılı̆̆ın bulunduğunu göstermektedir. Son-test ile ilk izleme testi puanları arasında I. izleme testi lehine anlamlı bir farklılığın bulunduğu saptanmıştır. Son-test ve II. izleme testi puanları arasında anlamlı bir farklılığın bulunmadığı saptanmıştır. İzleme ölçümleri arasında ise anlamlı bir farklılığın bulunmadığı saptanmıştır. Elde edilen bu sonuç; 
iletişim ve çatışma çözme beceri eğitimi alan öğrencilerin sosyal beceri düzeylerinin, uygulama sonrasında yapılan ölçümlerde anlamlı düzeyde yükseldiğini göstermektedir. Uygulama sonrasındaki sosyal beceri düzeylerinin ise üç ve altı ay sonra yapılan izleme çalışmalarındaki ölçüm sonuçlarından olumsuz düzeyde bir farklılaşmanın bulunmadığını, yani uygulamanın etkisinin devam ettiğini göstermektedir.

Tablo 4. Deney grubunda yer alan ögrencilerin SBE ön-test, son-test, I. izleme ve II. izleme testi toplam puanlarına ilişkin, İlişkili Örneklemler Iç̧in Tek Yönlü ANOVA Testi sonuçları

\begin{tabular}{|c|c|c|c|c|c|c|}
\hline $\begin{array}{l}\text { Varyansın } \\
\text { Kaynağı }\end{array}$ & $\begin{array}{l}\text { Kareler } \\
\text { Toplamı }\end{array}$ & sd & $\begin{array}{c}\text { Kareler } \\
\text { Ortalaması }\end{array}$ & $\mathrm{F}$ & $\mathrm{p}$ & Anlamlı Fark \\
\hline Deneklerarası & 40555.08 & 13 & 3119.62 & 143.35 & .000 & $\begin{array}{c}2-1,3-1,4-1, \\
3-2\end{array}$ \\
\hline Ölçüm & 111688.48 & 3 & 37229.49 & & & \\
\hline Hata & 9989.26 & 39 & 256.13 & & & \\
\hline Toplam & 162232.82 & 55 & & & & \\
\hline
\end{tabular}

\section{TARTIŞMA}

$\mathrm{Bu}$ araştırmada araştırmacı tarafından geliştirilen İletişim ve Çatışma Çözme Beceri Eğitimi Programı'nın, üniversite öğrencilerinin sosyal beceri düzeyleri üzerindeki etkisi incelenmiştir. Bu amaçla sosyal beceri düzeyi düşük olan öğrencilerden $14^{\prime}$ er kişilik deney ve kontrol grupları oluşturulmuştur. Günlük sosyal ilişkilerinde yaşadıkları iletişim sorunlarını işbirliği kurarak daha etkili bir biçimde çözebilmelerine ve daha uyumlu bir sosyal yaşantı sürmelerine yardımcı olma amacıyla, deney grubunda bulunan bireylere 10 oturum boyunca temel iletişim ve çatışma çözme becerileri eğitimi verilmiştir. $\mathrm{Bu}$ program ile üniversite öğrencilerinin; saldırgan tepkiler vermeden çatışmaları çözmelerine, iletişimde duygu ve düşüncelerini sağlıklı bir biçimde paylaşmalarına ve iletişimi sürdürmelerine yardımcı olunması hedeflenmiştir.

Araştırmada elde edilen bulgular; deney grubunun sosyal beceri düzeyinde anlamlı bir yükselme olduğunu, kontrol grubunun sosyal beceri düzeyinde ise anlamlı bir yükselmenin olmadığını göstermektedir. Deney grubunda yapılan iki ayrı izleme çalışmasında, öğrencilerin sosyal beceri düzeylerinde gözlenen olumlu değişmenin devam ettiği gözlenmiştir. Ulaşılan bu sonuç, deney grubuna verilen grup yaşantısına dayalı iletişim ve çatışma çözme beceri eğitiminin etkilerinin, uzun süreli ya da kalıcı olabileceğinin bir belirtisi olarak düşünülebilir. Program kapsamında; 
iletişimde tanışma, selamlaşma, kabul ve saygıyı iletebilme, ego geliştirici dil kullanabilme, etkin dinleme becerisini kullanabilme, olumlu ve olumsuz duygularını ben dili kullanarak ifade edebilme, empatik tepki verebilme, öfkeyi kontrol edebilme ve ben dili kullanarak ifade edebilme, çatışma karşısında saldırgan ve zorba tepki verme yerine işbirliğine dayalı çözüm tepkileri sergileme, iletişim ve çatışma sürecinde başkalarının beden dilini anlayabilme gibi becerileri kazandırmaya yönelik uygulamalar yapılmıştır. Deney grubunda geçirilen bu yaşantıların, bireylerin sosyal beceri düzeylerinin gelişmesinde etkili olduğu ileri sürülebilir. Ayrıca deney grubunda yer alan öğrencilerin geçmiş yaşantılarında bu becerileri kazanamadıkları ve bu durumun da günlük yaşantılarında bir yetersizlik durumu olarak karşılarına çıktığı da vurgulanabilir.

Yapılan araştırmaların bulguları; bireylerin sosyal beceri düzeylerini yükseltme amaciyla verilen sosyal beceri eğitiminin, bireylerin yeni ve işlevsel sosyal becerileri kazanmalarında olumlu yönde etkilerinin bulunduğunu göstermektedir (Anderson-Butcher, Newsome \& Nay, 2003; Antshel \& Remer, 2003; Bierman \& Furman, 1984; Boulton, 2003; Bullis, Walker \& Sprague, 2001; Cunliffe, 1992; Elliott, Pring \& Bunning, 2002; Goodwin, 1999; Leukefeld, Godlaski, Clark, Brown \& Hays, 2002; Ogilvy, 1994; Spence, 2003; Takahashi \& Kosaka, 2003; Thompson \& Bundy, 1996; Thompson \& Bundy, 1995; Wise \& Bundy, 1991; Yüksel, 1999). Bu programlar incelendiğinde çoğunlukla ilköğretim ve ortaöğretim öğrencilerine yönelik olduğu gözlenmektedir. Bu programların ortalama 812 oturum arasında değiştiği ve dinleme becerileri, öfke kontrolü, arkadaşlık, zorbalık ve atılganlık gibi konularda beceri eğitimine ağırlık verildiği gözlenmektedir. Bu becerilerin kazandırılmasında rol oynama, ödevlendirme ve model gösterme gibi yaklaşımların kullanıldı̆̆ı, izleme çalışmasının birkaç programda son-test uygulamasından üç ve altı ay sonra yapıldığı, bazı programlarda ise izleme çalışmasının yapılmadığı gözlenmektedir. $\mathrm{Bu}$ araştırmada kullanılan programda yukarıda belirtilen programlardan farklı olarak; iletişimde kabul ve saygıyı iletebilme, iletişimde karşıdaki bireyin beden dilini algılayabilme, işbirliğine dayalı çatışma çözme, ego geliştirici dil kullanma, iletişimde ben dili kullanarak duygularını paylaşma ve empatik tepki verebilme gibi becerilere yer verilmiştir. Yapılan literatür taramasında, psikolojik yardım mesleklerinin gelişmiş olduğu ülkelerde uygulanan sosyal beceri eğitimi programlarının, sayısal olarak Türkiye'de geliştirilen ve uygulamaya koyulan programlardan daha fazla olduğu gözlenmektedir.

Sonuç olarak, temel iletişim ve çatışma çözme beceri eğitimi verilen üniversite öğrencilerinin, sosyal beceri düzeylerinin geliştirilebildiği ve işlevsel düzeyde yeni sosyal beceriler kazanabildikleri gözlenmektedir. 
Araştırmada elde edilen bulgular doğrultusunda; sosyal beceri düzeyi düşük olan üniversite öğrencilerine yönelik olarak iletişim ve çatışma çözme beceri eğitimi programlarının yaygınlaştırılarak uygulamaya koyulması yararlı olabilir.

\section{KAYNAKLAR}

Abbott, P. \& Lewry, S. (1992). Front office: Procedures, social skills and management. Oxford: Butterworth Heinemann.

Anderson-Butcher, D., Newsome, W. S. \& Nay, S. (2003). Social skills intervention during elementary school recess: A visual analysis. Children \& Schools, 25(3), 135-146.

Antshel, K. M. \& Remer, R. (2003). Social skills training in children with attention deficit hyperactivity disorder: A randomized-controlled clinical trial. Journal of Clinical Child and Adolescent Psychology, 32(1), 153-165.

Baltaş, Z. ve Baltaş, A. (1992). Bedenin dili. 3. Bask1. İstanbul: Remzi Kitabevi.

Becker, R. E., Heimberg, G. R. \& Bellack, A. S. (1987). Social skills training treatment for depression. New York: Pergamon Press.

Begun, R. W. (1996). Ready - to-use. Social skills lessons and activities for grades 7 - 12. USA: Jossey - Bass A Wiley Imprint.

Bierman, K. L. \& Furman, W. (1984). The effect of social skills training and peer involvement on the social adjustment of preadolescents. Child Development, 55, 151-162.

Breunlin C. D., Bryant-Edwards, T. L. \& Hetherington, J. S. (2002). Conflict resolution training as an alternative to suspension for violent behavior. The Journal of Educational Research, 61(95), 349-357.

Bullis, M., Walker, H. M. \& Sprague, J. F. (2001). A promise unfulfilled: Social skills training with at-risk and antisocial children and youth. Exceptionality, 9(1-2), 67-90.

Büyüköztürk, Ş. (2003). Sosyal bilimler için veri analizi el kitabı. 3. Bask1. Ankara: Pegem A Yayıncılık.

Cartledge, G. \& Milburn, J. F. (1992). Teaching social skills to children. USA: Pergamon Book, Inc.

Cavell, T. A. (1990). Social adjustment, social performance, and social skills: A tri-component model of social competence. Journal of Clinical Child Psychology, 19(2), 111-122.

Cunliffe, T. (1992). Arresting youth crime: A review of social skills training with young offenders. Adolescence, 27(108), 891-901.

Cüceloğlu, D. (1995). Insan insana. İstanbul: Remzi Kitabevi, 9. Bask1.

Çağdaş, A. (2002). Anne-baba-çocuk iletişimi. Ankara: Nobel Yayın Dağıtım.

Dökmen, Ü. (1995). Iletiş̧im çatışmaları ve empati. 2. Baskı. İstanbul: Sistem Yayıncilik. 
Durant, R. H., Barkın, S. \& Krowchuk, P. D. (2001). Evaluation of a peaceful conflict resolution and violence prevention curriculum for sixth-grade students. Journal of Adolescent Health, 28, 386-393.

Dysinger, B. J. (1993). Conflict resolution for intermediate children. School Counselor, 40(4), 301-308.

Egan, G. (1975). Psikolojik danışmaya giriş. Çev: Akkoyun, F. ve Diğerleri. Ankara: Form Ofset.

Elksnin, L. K. \& Elksnin, N. (1998). Teaching social skills to students with learning and behavior problems. Intervention in School \& Clinic, 33(3), 131-141.

Elliott, S. N. \& Gresham, F. M. (1987). Children's social skills: Assessment and classification practices. Journal of Counseling and Development, 66, 9699.

Elliott, C., Pring, T. \& Bunning K. (2002). Social skills training for adolescents with intellectual disabilities: A cautionary note. Journal of Applied Research in Intellectual Disabilities, 15, 91-96.

Fontana, D. (1992). Problems in practice-social skills at work. Leicester: British Psychological Society, New.

Fox, C. L. \& Boulton, M. J. (2003). Evaluating the effectiveness of a social skills training (SST) programme for victims of bullying. Educational Research, 45(3), 231-247.

Gresham, F. M. (1986). Conceptual and definitional issues in the assessment of children's social skills: Implications for classification and training. Journal of Clinical Child Psychology, 15(1), 3-15.

Goodwin, M. W. (1999). Cooperative learning and social skills: What skills to teach and how to teach them. Intervention in School \& Clinic, 35(1), 29-34.

Gordon, T. (1998). Etkili ögretmenlik eğitimi, İstanbul: Sistem Yayıncılık, 4.Basim.

Gordon, T. ve Sands, J. G. (1998). Etkili anne baba eğitiminde uygulamalar. 3.Basım. İstanbul: SistemYayıncılık.

Graves, M., Nordling, G., Roberts, D. \& Taylor, C. (1997). Conflict resolution throug literature. Dissertation Theses Reports, 6-48.

Hamarta, E. (2000). Üniversite öğrencilerinin yalnızlık ve sosyal beceri düzeylerinin öğrencilerin özlük nitelikleri açısından incelenmesi. Konya: Selçuk Üniversitesi Sosyal Bilimler Enstitüsü Yayınlanmamış Yüksek Lisans Tezi.

Hansen, D. J., Nangle, D. W. \& Meyer, K. A. (1998). Enhancing the effectiveness of social skills interventions with adolescents. Education \& Treatment of Children, 21(4), 489-514.

Hargie, O., Sounders, C. \& Dickson, D. (1994). Social skills in interpersonal communication. USA: Routledge and Newyork.

Harman, J. P., Hansen, C. E., Cochran, M. E. \& Lindsey, C. R. (2005). Liar, Liar: Internet faking but not frequency of use affects social skills, self- 
esteem, social anxiety, and aggression. Cyber Psychology \& Behavior, $8(1), 1-6$.

Hazaleus, S. L. \& Deffenbacher, J. L. (1986). Relaxation and cognitive treatments of anger. Journal of Consulting and Clinical Psychology, 54(2), 222-226.

Huprich, S. K., Clancy, C., Bornstein, R. F., \& Nelson-Gray, R. O. (2004). Do dependency and social skills combine to predict depression? Linking two diatheses in mood disorders research. Individual Differences Research, 2(1), 2-16.

Inger, M. (1991). Conflict resolution programs in schools. Eric-Cue Digest, (74), 1-6.

Kelly, J. A. (1982). Social skills training: A practical guide for interventios. New York: Springer Publication Company.

Korkut, F. (2004). Okul temelli önleyici rehberlik hizmetleri. Ankara: Anı Yayıncilik.

Lane-Garon, S. P. (2000). Practicing peace: The impact of a school-based conflict resolution program on elementary students. Peace and Change, 25(4), 467-482.

Leukefeld, C. G., Godlaski, T., Clark, J., Brown, C. \& Hays, L. (2002). Structured stories: Reinforcing social skills in rural substance abuse treatment. Healt \& Social Work, 27(3), 213-217.

Matson, J. L., Smiroldo, B. B. \& Bamburg, J. W. (1998). The relationship of social skills to psychopathology for individuals with severe or profound mental retardation. Journal of Intellectual \& Developmental Disability, 23(2), 137-146.

McWhirter, J. ve Voltan-Acar, N. (1998). Çocukla iletişim. İstanbul: Milli Eğitim Basımevi.

Nangle, D. W. \& Hansen, D. J. (1998). New directions in the application of social-skills interventions with adolescents: Introduction to the special section. Education \& Treatment of Children, 21(4), 427-431.

Ogilvy, C. M. (1994). Social skills training with children and adolescents: A review of the evidence on effectiveness. Educational Psychology, 14(1), 73-84.

Pettit, N. (1995). Improving behavior of middle school students through a conflict resolution program for sixth grade. Dissertation Abstract Reports, 1-12.

Riggio R. E. (1986). Assessment of basic social skills. Journal of Personality and Social Psychology, 51(3), 649 - 660.

Riggio R. E., Tucker. J. \& Coffaro, D. (1989). Social Skills and Empathy. Personality and Indivudual Differences, 10(1), 93 - 99.

Schroeder, P. A., Basken, A., Engstrom, L. \& Heald, L. (2000). Using cooperative learning strategies to improve social skills. Dissertation Theses Reports, 4-39. 
Selçuk, Z. ve Güner, N. (2000). Sınıf içi rehberlik uygulamaları. Ankara: Pegem A Yayıncilık.

Segrin, C. (2001). Social skills and negative life events: Testing the deficit stress generation hypothesis. Current Psychology, 20(1), 19-35.

Spence, S. H. (2003). Social skills training with children and young people: Theory, evidence and practice. Child and Adolescent Mental Healt, 8(2), 84-96.

Spirito, A. \& Hartford, K. (1990). Social skills and depression in adolescent suicide attempters. Adolescence, 25(99), 543-553.

Stevahn, L. \& Johnson, D. W. (1997). Effects on high school students of conflict resolution training integrated into English literatüre. Journal of Social Psychology, 137(3), 302-311.

Takahashi, M. \& Kosaka, K. (2003). Efficacy of open-system social skills training in inpatients with mood, neurotic and eating disorders. Psychiatry and Clinical Neurosciences, 57, 295-302.

Thompson, K. L. \& Bundy, K. A. (1995). Social skills training for young adolescents: Symbolic and behavioral components. Adolescence, 30(119), 723-735.

Thompson, K. L. \& Bundy, K. A. (1996). Social skills training for young adolescents: Cognitive and performance components. Adolescence, 31(123), 505-522.

Ural, A. ve Kılıç, İ. (2005). Bilimsel araştırma süreci ve SPSS ile veri analizi. Ankara:Detay Yayıncilik.

Voltan-Acar, N. (2002). Grupla psikolojik danışmada alıştırmalar ve deneyler. Ankara: Nobel Yayın Dağıtım.

Wise, K. L. \& Bundy, K. A. (1991). Social skills training for young adolescents. Adolescence, 26(101), 233-242.

Yüksel, G. (1999). Sosyal beceri eğitiminin üniversite öğrencilerinin sosyal beceri düzeylerine etkisi. Türk Psikolojik Danışma ve Rehberlik Dergisi, II(11), 37-47.

Yüksel, G. (2000). Sosyal beceri envanteri el kitabı. Ankara: Asil Yayın Dağıtım. 